\title{
Sheep dung disappearance from grazed hill country landscapes
}

\author{
Ronaldo VIBART*, Alec MACKAY, Brian DEVANTIER, Emma NOAKES and Paul MACLEAN \\ AgResearch, Grasslands Research Centre, Tennent Drive, \\ Private Bag 11008, Palmerston North 4442, New Zealand. \\ *Corresponding author: Ronaldo.vibart@agresearch.co.nz
}

\begin{abstract}
Two experiments were conducted to examine the effects of biological and topographic factors affecting sheep dung disappearance rates in hill country pastures. Three farmlets were used from the longterm phosphorus fertiliser trial at Ballantrae, that had received either $0(\mathrm{NF}), 125(\mathrm{LF})$ or $375(\mathrm{HF}) \mathrm{kg}$ of single superphosphate/ha since 1980. Experiment 1 examined the effect of farmlet, slope (low and medium slope class) and aspect (E, SW, NW), whereas Experiment 2 examined the effect of farmlet, both as a source of dung (from sheep grazing the LF or the HF farmlet) and as a deposition site (applied on the LF or HF farmlet). Despite a lower fibre concentration, dung from sheep grazing the HF farmlet did not disappear at a faster rate than dung from other farmlets, but soil activity in situ was most influential for the rate of dung disappearance. A faster rate of dung disappearance on the HF farmlet was consistent with a greater capacity of turnover of plant biomass and animal excreta in this high fertility environment. These experiments contribute to the understanding the biological and topographic drivers of dung disappearance rates, and enable further advances in the modelling of nutrients in topographically complex agroecosystems.
\end{abstract}

Keywords: Animal excreta, ruminants, soil, topography, soil nutrient dynamics.

\section{Introduction}

Ruminants play an important role in nutrient cycling in grazed grasslands. Nutrients recycled back to the soilpasture system via animal excreta are a significant input to soils in these production systems, and increases in soil fertility and pasture nutrition have been observed in response to these nutrients (Haynes and Williams 1993; Sakadevan et al., 1993). Soil microbial activity is stimulated by nutrients recycled in animal dung, and, as nutrients become available for plant uptake, they influence pasture species composition and yield (Aarons et al., 2009).

The importance of livestock dung in the soil-plantgrazing-animal continuum is primarily related to the large amounts of nutrients (derived from feed intake) applied to pastures and the pathways that these nutrients follow to be reincorporated into the soil. Published sheep dung disappearance rates differ considerably, since factors, such as local climate, soil conditions, and dung consistency, alter decomposition (Williams and Haynes 1995; Shand and Coutts 2006; Bahamonde et al., 2017). Modelling efforts to capture long-term soil phosphorus $(\mathrm{P})$, organic carbon $(\mathrm{C})$ and nitrogen (N) dynamics under hill country grazing have shown that animal dung is an important contributor to the flux of $\mathrm{P}, \mathrm{C}$ and $\mathrm{N}$ through these systems (Hoogendoorn et al., 2011; Bilotto et al., 2019). However, there is a lack of information on the integration of biological and topographic drivers of nutrient cycling in these complex landscapes. Using above-ground dung disappearance as a proxy, this project examined the effects of biological (e.g., dung chemical composition and deposition site) and topographic (e.g., slope and aspect) factors leading to dung disappearance. It was hypothesised that both biological and topographic factors would affect the rate of sheep dung disappearance over time. Two experiments were designed to explore the effects of dung chemical composition, slope and aspect (Experiment 1) and dung chemical composition and deposition site (Experiment 2) on the rate of disappearance of dung from sheep grazing hill country pastures.

\section{Materials and Methods \\ Experimental site}

The experiments were undertaken at the Ballantrae Hill Country Research Station from May $21^{\text {st }}$ to October $1^{\text {st }}$, 2020. The self-contained farmlets used to examine these effects have been described elsewhere (Mackay et al., 2021). Briefly, the no fertility (NF; 9.7 ha), low fertility (LF; 8.1 ha) and high fertility (HF; 6.8 ha) farmlets had been receiving an annual rate of 0,125 or $375 \mathrm{~kg}$ of single superphosphate (SSP; 0-9-0-11) per hectare since 1980. These farmlets have been in place since 1975 and were stocked with breeding ewes in response to herbage growth rates in an attempt to maintain a similar grazing pressure across farmlets, i.e., similar number of stocking units per unit of pasture production (Mackay et al., 2021). Landscape topographical features at Ballantrae were typical of a large proportion of North 
Island hill country grazing environments (Blaschke et al., 1992), with soils classified as Brown and Pallic soils largely with imperfectly drained silt-loam textures (Hewitt 1998; Lambert et al., 2000).

Experiment 1 examined the effect of farmlet, i.e., dung collected from sheep grazing on each of the three farmlets, with dung applied exclusively on their corresponding farmlet, slope (low slope class $\left(<12^{\circ}\right)$ and medium slope class $\left(12-24^{\circ}\right)$ ), and aspect (East (E), Southwest (SW), and Northwest (NW)) on dung disappearance over time. Given the lesser amounts of dung deposited on the steepest slopes (Rowarth 1987), the disappearance rates on the steepest slope class $\left(>24^{\circ}\right)$ were not examined. Experiment 2 examined the effect of farmlet, both as a 'source' of dung (collected from the LF or HF farmlet) and as a 'deposition site' (i.e., dung placed on the LF or HF farmlet), over the same 19-week time period.

\section{Soils and pastures}

Soil samples were collected from each farmlet following the procedure described by Mackay et al. (2021). Briefly, 20 soil cores were collected and bulked for chemical and physical analysis at each of the 12 sites within farmlets ( 2 slopes $\times 3$ aspects $\times 2$ reps). Bulked soil samples were analysed for $\mathrm{pH}$ in water, total $\mathrm{N}, \mathrm{C}$ and $\mathrm{P}$, Olsen $\mathrm{P}$, sulphate-S and extractable organic $\mathrm{S}$, and exchangeable cations via a commercial laboratory. The cores were extracted in depth increments, up to a 300-mm depth, but the results reported herein are those obtained from the analysis of the topsoil $(0-75 \mathrm{~mm})$.

Herbage samples were collected from each farmlet on April $29^{\text {th }}, 2020$. These were collected from both exclusion cages and grazed pastures for chemical analysis and botanical composition, following the procedures described by Lambert et al. (2014). Herbage samples collected from exclusion cages (six per farmlet) and grazed pastures (six per farmlet) were obtained from the medium slope, and were analysed for concentrations of dry matter (DM), organic matter $(\mathrm{OM}), \mathrm{OM}$ digestibility $(\mathrm{OMd})$, crude protein $(\mathrm{CP})$, soluble $\mathrm{CP}$, neutral detergent fibre (NDF), acid detergent fibre (ADF), acid detergent lignin (ADL), soluble sugars and starch (SSS), fat, and minerals using near infrared (NIR) spectroscopy. Separation of plant green tissue (into perennial ryegrass, other grasses, white clover, other legumes and other species) from dead tissue was conducted according to Lambert et al. (1986).

\section{Dung}

Both experiments started in late May 2020, and lasted for 19 weeks before all dung disappeared. Fresh sheep dung was collected from each of the farmlets and mixed thoroughly. Subsamples were taken for NIR analysis and DM concentration analysis, and dung was ovendried and ground to less than $2 \mathrm{~mm}$ prior to chemical analysis. Prior to on-pasture application, the following procedure was used. A total of $70 \mathrm{~g}$ of dung fresh weight (based on an initial assessment of DM; the aim was to apply $20 \mathrm{~g}$ of DM) was placed in nylon mesh bags with an ear tag label and tied with cable tie (a 'unit'; a total of 280 units used). These were placed in plastic bags and stored under refrigeration until applied on the pasture. Once on site, 180 units were used in Experiment 1, and 100 units were used in Experiment 2. Units were placed on each site and covered with a plastic squared mesh and pinned to the ground with tent pegs. Dung samples were retrieved on days $15,22,29,35,43,50,63,85$, 106 and 124 after the initial application on pasture (day 0 ). All fresh weights were recorded, and samples were subsequently dried in a forced-air oven at $60^{\circ} \mathrm{C}$ for $48 \mathrm{~h}$ until stable dry weight was obtained.

\section{Statistical analysis}

The disappearance of dung was analysed using Restricted Estimate Maximum Likelihood (REML) analysis in the lme4 $\mathrm{R}$ package version 4_1.1-26 (Bates et al., 2015) in $\mathrm{R}$ version 4.02 (R Core Team 2020). In Experiment 1, plot was the random effect, and farmlet (three levels), slope (two levels) and aspect (three levels) were the factors of interest, along with time on pasture (i.e., days for sample collection relative to day 0 ) as a quadratic term. Similarly in Experiment 2, plot and dung (both as a source and deposition site with two levels each) were the random and fixed factors of interest, respectively, along with time on pasture as a quadratic term. The model terms were evaluated using type III ANOVA with Satterthwaite's method with the lmerTest package version 3.1-3 (Kuznetsova et al., 2017).

\section{Results}

Soils at the selected Ballantrae farmlets had high organic matter $(\mathrm{OM})$ and total carbon $(\mathrm{C})$ concentrations and were slightly acidic (Table 1). Total soil nitrogen (N) and $\mathrm{C}$ concentrations, as well as bulk density values, were similar across farmlets, despite large differences in pasture production associated with high $\mathrm{P}$ inputs (Mackay et al., 2021). Olsen P values across farmlets were a consequence of sustained varying $\mathrm{P}$ inputs over the last four decades (Table 1).

For both exclusion cages and grazed pasture sites on medium slopes, numerical differences in herbage DM and $\mathrm{CP}$ concentrations, along with differences in $\mathrm{OMd}$ and ME values, were seen across farmlets (Table 2). Although no statistical analysis was performed, the linear increases in $\mathrm{P}$, potassium $(\mathrm{K})$, sulphur $(\mathrm{S})$, calcium (Ca) and cadmium $(\mathrm{Cd})$ concentrations from NF to HF herbage reflected the varying $P$ inputs on these farmlets 
Table 1 Soil chemical and physical composition of samples $(0-75 \mathrm{~mm})$ collected from the different farmlets

\begin{tabular}{|c|c|c|c|c|c|}
\hline \multirow{3}{*}{ Item } & \multicolumn{3}{|c|}{ Experiment 1} & \multicolumn{2}{|c|}{ Experiment 2} \\
\hline & \multirow{2}{*}{$\begin{array}{c}\text { Farmlet } \\
\text { NF }\end{array}$} & \multicolumn{2}{|c|}{ Farmlet } & \multirow[b]{2}{*}{ LF } & \multirow[b]{2}{*}{ HF } \\
\hline & & LF & HF & & \\
\hline $\mathrm{OM}, \%$ & 9.6 & 9.2 & 10.0 & 13.6 & 12.6 \\
\hline Total N, \% & 0.43 & 0.42 & 0.47 & & \\
\hline Total C, \% & 5.6 & 5.3 & 5.8 & 7.9 & 7.3 \\
\hline Soil pH & 5.4 & 5.3 & 5.3 & 5.5 & 5.6 \\
\hline Bulk density, $\mathrm{Mg} / \mathrm{m}^{3}$ & 0.85 & 0.87 & 0.84 & & \\
\hline Olsen P, mg/l & 3.6 & 11.8 & 64.0 & $<2.0$ & 52.0 \\
\hline
\end{tabular}

No fertility (NF), low fertility (LF) and high fertility (HF) farmlets that have been receiving an annual rate of either 0,125 or $375 \mathrm{~kg} / \mathrm{ha}$ of single superphosphate (SSP) since 1980, respectively.

Table 2 Chemical and botanical composition of herbage collected from the medium slope of the three farmlets.

\begin{tabular}{|c|c|c|c|c|c|c|}
\hline \multirow[t]{3}{*}{ Item } & \multicolumn{6}{|c|}{ Farmlet } \\
\hline & NF & LF & HF & NF & LF & HF \\
\hline & \multicolumn{3}{|c|}{ Exclusion cage } & \multicolumn{3}{|c|}{ Grazed pasture } \\
\hline \multicolumn{7}{|c|}{ Chemical composition (\% DM unless stated otherwise) } \\
\hline DM, \% & 29.0 & 26.5 & 22.0 & 39.0 & 35.5 & 32.7 \\
\hline $\mathrm{OM}$ & 90.0 & 88.6 & 89.0 & 87.9 & 89.0 & 84.7 \\
\hline $\mathrm{CP}$ & 15.8 & 19.2 & 19.2 & 11.8 & 14.7 & 14.4 \\
\hline Soluble CP, \% CP & 38.3 & 39.0 & 41.7 & 35.3 & 40.8 & 38.0 \\
\hline NDF & 57.4 & 53.4 & 53.4 & 56.4 & 56.9 & 55.2 \\
\hline NDFd, \% NDF & 40.7 & 49.3 & 56.0 & 35.0 & 37.2 & 41.0 \\
\hline ADF & 27.3 & 25.3 & 27.1 & 27.7 & 27.6 & 29.3 \\
\hline ADL & 3.9 & 3.9 & 3.3 & 4.1 & 4.1 & 4.3 \\
\hline SSS & 6.7 & 5.5 & 6.7 & 5.7 & 4.9 & 4.6 \\
\hline Fat & 3.2 & 3.4 & 3.3 & 2.5 & 2.7 & 2.2 \\
\hline OM digestibility & 57.0 & 59.1 & 61.4 & 50.7 & 53.6 & 48.7 \\
\hline ME, MJ/kg DM & 9.1 & 9.5 & 9.8 & 8.1 & 8.6 & 7.8 \\
\hline$P$ & 0.19 & 0.24 & 0.42 & 0.16 & 0.22 & 0.35 \\
\hline K & 1.68 & 2.10 & 2.73 & 0.97 & 1.16 & 1.45 \\
\hline S & 0.24 & 0.27 & 0.36 & 0.19 & 0.22 & 0.28 \\
\hline $\mathrm{Ca}$ & 0.49 & 0.55 & 0.62 & 0.50 & 0.52 & 0.65 \\
\hline $\mathrm{Cd}, \mathrm{mg} / \mathrm{kg} \mathrm{DM}$ & 0.09 & 0.14 & 0.26 & 0.12 & 0.22 & 0.55 \\
\hline
\end{tabular}

Botanical composition (\% DM unless stated otherwise)

\begin{tabular}{|c|c|c|c|c|c|c|}
\hline Green $(\mathrm{G})$ tissue & 69.3 & 77.8 & 79.9 & 43.2 & 50.2 & 51.4 \\
\hline Ryegrass, \% G & 0.4 & 14.5 & 30.4 & 4.4 & 11.0 & 32.6 \\
\hline Other grasses, \% G & 86.6 & 76.5 & 50.4 & 76.0 & 70.7 & 53.8 \\
\hline White clover, \% G & 2.9 & 2.2 & 12.0 & 4.0 & 3.4 & 8.0 \\
\hline Other legumes, \% G & 0.5 & 2.0 & 4.1 & 0.0 & 0.5 & 1.5 \\
\hline Other species, \% G & 8.1 & 3.6 & 3.0 & 7.4 & 4.8 & 3.6 \\
\hline
\end{tabular}

No fertility (NF), low fertility (LF) and high fertility (HF) farmlets that have been receiving an annual rate of either 0,125 or $375 \mathrm{~kg} / \mathrm{ha}$ of single superphosphate (SSP) since 1980, respectively. 
(Table 2). Perennial ryegrass, as a percentage of total plant vegetative DM tissue, increased from 0.4 and $4.4 \%$ in NF herbage to 30.4 and $32.6 \%$ in HF herbage in both exclusion cages and grazed pasture samples, respectively. The percentage of other grasses and other species (i.e., weeds) followed the opposite trend in both sampling sites.

The fibre (NDF) concentration of sheep dung was lower $(\mathrm{P}=0.02)$, and the $\mathrm{P}$ and $\mathrm{Cd}$ concentrations of dung were higher $(\mathrm{P}=0.01$ and $\mathrm{P}<0.001$, respectively) from the HF farmlet compared with the other two farmlets (Table 3). Total $\mathrm{C}$ and $\mathrm{N}$ concentrations in dung were similar across farmlets.

As expected, time on pasture had a significant effect $(\mathrm{P}<0.001)$ on dung disappearance, when expressed as dung remaining in both experiments (Table 4).

Table 3 Chemical composition of sheep dung collected from the three farmlets

\begin{tabular}{|c|c|c|c|c|c|c|c|}
\hline \multirow[t]{3}{*}{ Item } & \multicolumn{6}{|c|}{ Farmlet } & \multirow[t]{3}{*}{$P$ value } \\
\hline & \multicolumn{2}{|c|}{ NF } & \multicolumn{2}{|c|}{ LF } & \multicolumn{2}{|c|}{ HF } & \\
\hline & Mean & SE & Mean & SE & Mean & SE & \\
\hline OM, \% & 69.5 & 2.3 & 69.4 & 3.2 & 71.7 & 2.7 & 0.80 \\
\hline NDF, \% & $54.1^{\mathrm{a}}$ & 0.8 & $52.1^{\mathrm{a}}$ & 1.7 & $46.4^{\mathrm{b}}$ & 2.5 & 0.02 \\
\hline ADF, $\%$ & 38.8 & 1.4 & 38.8 & 1.7 & 33.6 & 1.3 & 0.06 \\
\hline Total C, \% & 40.3 & 1.3 & 40.2 & 1.8 & 41.6 & 1.6 & 0.81 \\
\hline Total N, \% & 2.23 & 0.13 & 2.17 & 0.13 & 2.65 & 0.19 & 0.11 \\
\hline $\mathrm{P}, \%$ & $0.54^{\mathrm{a}}$ & 0.07 & $0.73^{b}$ & 0.08 & $1.13^{c}$ & 0.18 & 0.01 \\
\hline $\mathrm{K}, \%$ & 1.08 & 0.21 & 0.85 & 0.08 & 1.42 & 0.56 & \\
\hline $\mathrm{S}, \%$ & 0.32 & 0.01 & 0.33 & 0.02 & 0.35 & 0.01 & \\
\hline $\mathrm{Cd}, \mathrm{mg} / \mathrm{kg} \mathrm{DM}$ & $0.25^{a}$ & 0.03 & $0.38^{b}$ & 0.03 & $0.68^{\mathrm{c}}$ & 0.05 & $<0.001$ \\
\hline
\end{tabular}

No fertility (NF), low fertility (LF) and high fertility (HF) farmlets that had been receiving an annual rate of either 0,125 or $375 \mathrm{~kg} / \mathrm{ha}$ of single superphosphate (SSP) since 1980, respectively. Numbers with different superscripts differ $(P<0.05)$.

Table 4 Type III analysis of variance (ANOVA) structure and factors affecting sheep dung disappearance from different farmlets

\begin{tabular}{|c|c|c|c|c|}
\hline \multirow[t]{2}{*}{ Factor } & \multicolumn{2}{|c|}{ Experiment 1} & \multicolumn{2}{|c|}{ Experiment 2} \\
\hline & Levels & p-value & Levels & $P$ value \\
\hline Slope (low or medium slope) & 2 & 0.10 & & \\
\hline Aspect (E, NW or SW) & 3 & 0.29 & & \\
\hline Farmlet (dung from sheep on NF, LF or HF) & 3 & 0.48 & & \\
\hline Time (days on pasture as a quadratic term) & 3 & $<0.001$ & 3 & $<0.001$ \\
\hline Slope $\times$ Aspect & 6 & 0.30 & & \\
\hline Slope $\times$ Farmlet & 6 & 0.36 & & \\
\hline Aspect $\times$ Farmlet & 9 & 0.07 & & \\
\hline Slope $\times$ Time & 6 & 0.21 & & \\
\hline Aspect $\times$ Time & 9 & 0.26 & & \\
\hline Farmlet $\times$ Time & 9 & 0.04 & & \\
\hline Source (dung from sheep on LF or HF) & & & 2 & 0.79 \\
\hline Deposition site (dung placed on LF or HF) & & & 2 & $<0.001$ \\
\hline Source $\times$ Deposition site & & & 4 & 0.95 \\
\hline Source $\times$ Time & & & 6 & 0.86 \\
\hline Deposition site $\times$ Time & & & 6 & $<0.001$ \\
\hline
\end{tabular}

No fertility (NF), low fertility (LF) and high fertility (HF) farmlets that had been receiving an annual rate of either 0,125 or $375 \mathrm{~kg} / \mathrm{ha}$ of single superphosphate (SSP) since 1980, respectively. 


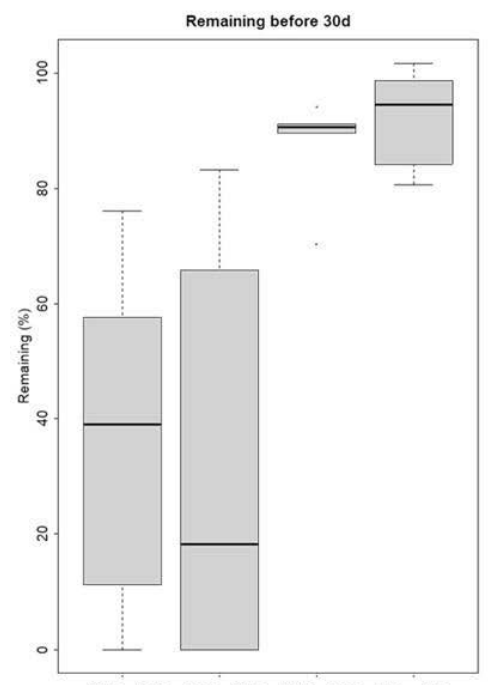

HF : HF LF : HF HF : LF LF : LF Source : Deposition site

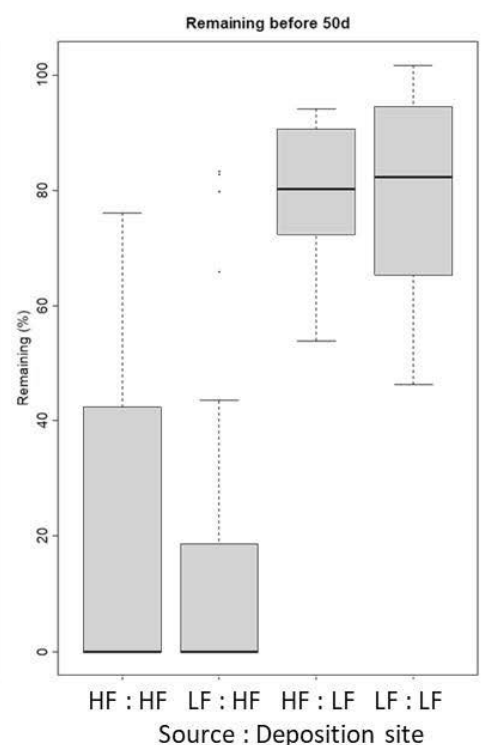

Figure 1 Sheep dung remaining after 30, 50 and 90 days on the farmlets (no fertility (NF), low fertility (LF) and high fertility (HF) farmlets that have been receiving an annual rate of either 0,125 or $375 \mathrm{~kg} / \mathrm{ha}$ of single superphosphate (SSP) per hectare since 1980, respectively).

In experiment 1 , there was an aspect $\mathrm{x}$ farmlet trend $(\mathrm{P}=0.07)$; specifically, where the NW aspect showed a slower rate of dung disappearance but only in dung collected from the NF and LF farmlets, compared with dung collected from the HF farmlet. A farmlet $\mathrm{x}$ time interaction on pasture $(\mathrm{P}=0.04)$ was due to the change in shape of the dung disappearance curve over time.

In Experiment 2, dung deposition site (but not source) and deposition site $\mathrm{x}$ time on pasture were significant $(\mathrm{P}<0.001)$. Before day 60, dung placed on the HF farmlet disappeared at a much faster rate than on the LF farmlet, but this difference tended to lessen after that period, especially in the LF source to LF deposition site (LF:LF; Figure 1). In both experiments, dung disappearance showed the best fit as a quadratic curve, but no improvements were seen in $\mathrm{r}^{2}$ using higher-order polynomials.

\section{Discussion}

Despite lower fibre concentration (NDF; Table 3), dung from sheep grazing the HF farmlet did not disappear at a faster rate than from the other two farmlets (Experiment 1). This was confirmed in Experiment 2, where dung collected from the HF farmlet did not disappear at a faster rate than that collected from the LF farmlet. Dung on NW-facing slopes (which are often prone to more severe moisture stress) disappeared at a slower rate in two of the three farmlets. Conversely, deposition site (i.e., site where the dung was applied) was pivotal to the rate of dung disappearance, especially during the first 8 weeks.
Sheep faecal matter comprises undigested feed constituents, endogenous secretions, bacteria, and water (Waghorn et al., 1999), characteristically packed in the form of pellets or pads, depending on the moisture and structural carbohydrate concentration of the diet (Haynes and Williams 1993). The dung applied in this experiment was more pellet type, and had a mean DM concentration of $27 \%$, slightly drier that that reported for sheep pellets (Williams and Haynes 1995) which was consistent with values reported for sheep grazing temperate grass-clover diets in New Zealand (Waghorn et al., 1999). Concentrations of fibre (both ADF and NDF) were consistent with sheep dung values reported from New Zealand (Waghorn et al., 1999) and elsewhere (Arnuti et al., 2020). The higher NDF concentrations in dung collected from sheep grazing the NF and LF farmlets, compared with dung collected from the HF farmlet, were likely attributable to numerically higher dietary fibre concentrations and lower digestibility of herbage, which was a consequence of the lower contribution of perennial ryegrass and legumes in the diet (Table 2).

In grazed pastures, significant quantities of nutrients are recycled annually in animal dung. For example, dung $\mathrm{P}$ is the prevalent pathway for animal returns to grazed pastures (Haynes and Williams 1993). This is far from being evenly distributed on the landscape (Bilotto et al., 2019); rather, it is returned in small areas at high concentrations (Gillingham, 1980). The concentration of $\mathrm{P}$ in dung from grazing ruminants is often much greater than in the herbage consumed, and 
has been reported to be up to a four-fold greater (Shand and Coutts 2006). In the current study, the ratio of $P$ in dung $v$ s. grazed pasture ranged from $3.4(\mathrm{NF})$ to 3.2 (HF), which was consistent with previous findings. This confirmed the significant relationship between $\mathrm{P}$ concentration in herbage on offer (i.e., grazed pasture in Table 2) and P concentration in dung deposited over time, as seen in other studies (Rowarth et al., 1985).

The decomposition of dung has often been associated with its chemical constituents, which in turn has been linked to the nutritive value of the herbage consumed (Shand et al., 2006). In the current study, the deposition site (i.e., site where the dung was applied), rather than dung origin and chemical composition, had the biggest influence on the rate of disappearance during winter and spring. The faster rate of disappearance of dung applied on the HF sites was consistent with changes in the soil microbial pool size, associated with the fungal population (Parfitt et al., 2010) and with greater earthworm biomass, diversity and activity in the HF farmlet (Schon et al., 2019). This led to more rapid cycling of nutrients, which suggested a greater capacity for turnover of plant shoot and root biomass and animal faeces from these sites.

\section{Conclusions}

The faster rate of dung disappearance on the high fertility farmlet (the 'site history' effect) was consistent with a greater capacity for turnover of plant biomass and animal excreta in this environment. This was in agreement with the minimal long-term impact of $\mathrm{P}$ fertility (and associated livestock carrying capacity) on soil $\mathrm{C}$ accumulation across these farmlets (Mackay et al., 2021). These experiments contributed to understanding of the influence of biological and topographic drivers of dung disappearance rates in hill country landscapes, and enabled further advances to be made in the modelling of nutrients and contaminants in these topographically complex agroecosystems.

\section{ACKNOWLEDGEMENTS}

The authors are grateful for all of the contributions made by science, technical and farm staff involved in the long-term fertiliser trial conducted at the AgResearch Hill Country Research Station, Ballantrae since its establishment more than four decades ago. This research was supported by the AgResearch Strategic Science Investment Fund.

\section{REFERENCES}

Aarons S, O'Connor C, Hosseini H, Gourley C. 2009. Dung pads increase pasture production, soil nutrients and microbial biomass carbon in grazed dairy systems. Nutrient Cycling in Agroecosystems 84: 8192. http://dx.doi.org/10.1007/s10705-008-9228-5
Arnuti F, Denardin LGdO, Nunes PAdA, Alves LA, Cecagno D, de Assis J, Schaidhauer WdS, Anghinoni I, Chabbi A, César de F. Carvalho P. 2020. Sheep dung composition and phosphorus and potassium release affected by grazing intensity and pasture development stage in an integrated crop-livestock system. Agronomy 10: 1162. https://www.mdpi. com/2073-4395/10/8/1162

Bahamonde HA, Gargaglione V, Peri PL. 2017. Sheep faeces decomposition and nutrient release across an environmental gradient in Southern Patagonia. Ecología Austral 27: 18-28.

Bates D, Maechler M, Bolker B, Walker S. 2015. Fitting Linear Mixed-Effects Models Using 1me4. Journal of Statistical Software 67: 1-48.

Bilotto F, Vibart R, Mackay A, Costall D. 2019. Modelling long-term changes in soil phosphorus and carbon under contrasting fertiliser and grazing management in New Zealand hill country. Journal of New Zealand Grasslands 81: 171-178. https://doi. org/10.33584/jnzg.2019.81.397

Blaschke PM, Trustrum NA, DeRose RC. 1992. Ecosystem processes and sustainable land use in New Zealand steeplands. Agriculture, Ecosystems \& Environment 41: 153-178. https://doi. org/10.1016/0167-8809(92)90107-M

Gillingham AG. 1980. Phosphorus uptake and return in grazed, steep hill pastures. New Zealand Journal of Agricultural Research 23: 313-321. https://doi.org/1 $0.1080 / 00288233.1980 .10425362$

Haynes RJ, Williams PH. 1993. Nutrient cycling and soil fertility in the grazed pasture ecosystem. Advances in Agronomy 49: 119-199. https://doi. org/10.1016/S0065-2113(08)60794-4

Hewitt AE. 1998. New Zealand Soil Classification. Landcare Research Science Series 1, 2nd edition, Manaaki Whenua Press, Lincoln, New Zealand.

Hoogendoorn CJ, Bowatte S, Tillman RW. 2011. Simple models of carbon and nitrogen cycling in New Zealand hill country pastures: exploring impacts of intensification on soil C and N pools. New Zealand Journal of Agricultural Research 54: 221-249. http:// dx.doi.org/10.1080/00288233.2011.599395

Kuznetsova A, Brockhoff PB, Christensen RHB. 2017. lmerTest Package: Tests in Linear Mixed Effects Models. Journal of Statistical Software 82: 1-26. https://doi.org/10.18637/jss.v082.i13

Lambert MG, Clark DA, Grant DA, Costall DA. 1986. Influence of fertiliser and grazing management on North Island moist hill country 2. Pasture botanical composition. New Zealand Journal of Agricultural Research 29: 1-10. https://doi.org/10.1080/0028823 3.1986.10417968

Lambert MG, Clark DA, Mackay AD, Costall DA. 2000. Effects of fertiliser application on nutrient 
status and organic matter content of hill soils. New Zealand Journal of Agricultural Research 43: 127138. https://doi.org/10.1080/00288233.2000.95134 14

Lambert MG, Mackay AD, Ganesh S, Upsdell MP. 2014. Responses of grazed New Zealand hill pastures to rates of superphosphate application. New Zealand Journal of Agricultural Research: 1-16. http://dx.doi. org/10.1080/00288233.2014.898663

Mackay AD, Vibart R, McKenzie C, Costall D, Bilotto F, Kelliher FM. 2021. Soil organic carbon stocks in hill country pastures under contrasting phosphorus fertiliser and sheep stocking regimes, and topographical features. Agricultural Systems 186: 102980. https://doi.org/10.1016/j.agsy.2020.102980

Parfitt RL, Yeates GW, Ross DJ, Schon NL, Mackay AD, Wardle DA. 2010. Effect of fertilizer, herbicide and grazing management of pastures on plant and soil communities. Applied Soil Ecology 45: 175-186. https://doi.org/10.1016/j.apsoil.2010.03.010

R Core Team. 2020. R: A language and environment for statistical computing. R Foundation for Statistical Computing, Vienna, Austria. https://www.R-project. org/.

Rowarth JS. 1987. Phosphate cycling in grazed hill-country pasture. A thesis presented in partial fulfillment of the requirements for the degree of Doctor of Philosophy in Soil Science at Massey University, $371 \mathrm{p}$.
Rowarth JS, Gillingham AG, Tillman RW, Syers JK. 1985. Release of phosphorus from sheep faeces on grazed, hill country pastures. New Zealand Journal of Agricultural Research 28: 497-504. https://doi.org /10.1080/00288233.1985.10417995

Sakadevan K, Mackay A, Hedley M. 1993. Influence of sheep excreta on pasture uptake and leaching losses of sulfur, nitrogen and potassium from grazed pastures. Soil Research 31: 151-162. https://doi. org/10.1071/SR9930151

Schon NS, Mackay AD, Gray RA. 2019. Changes in the abundance and diversity of earthworms in hill soils under different long-term fertiliser and sheep stocking regimes. New Zealand Journal of Agricultural Research 64: 162-177. https://doi.org/1 $0.1080 / 00288233.2019 .1581238$

Shand CA, Coutts G. 2006. The effects of sheep faeces on soil solution composition. Plant and Soil 285: 135-148. https://doi.org/10.1007/s11104-006-0065-5

Waghorn GC, Gregory NG, Todd SE, Wesselink R. 1999. Dags in sheep; a look at faeces and reasons for dag formation. Proceedings of the New Zealand Grassland Association 61: 43-49.

Williams PH, Haynes RJ. 1995. Effect of sheep, deer and cattle dung on herbage production and soil nutrient content. Grass and Forage Science 50: 263-271. https://doi.org/10.1111/j.1365-2494.1995. tb02322.x 